\title{
EFFORTS FOR THE ESTABLISHMENT OF AKHLAK THROUGH TASAWUF APPROACH IN THE COMMUNITY OF NTORI, BIMA DISTRICT
}

\author{
Abdullah Thalib \\ Fakultas Ushuluddin dan Filsafat \\ UIN Alauddin Makassar \\ Email: abdullah.thalib@uin-alauddin.ac.id
}

\begin{abstract}
This article is the result of a descriptive qualitative study on the thinking of a community leader in Ntori Village, Bima Regency named H. Usman Mustakim. Appointed as an appreciation for his dedication to the formation of morals in society as a reflection of a complete human being who is not only knowledgeable but also has to have morals. This research uses the Sufism approach, with the data collection method of observation, interviews, and documentation. The data analysis process includes data collection, data verification, and validation, and concluding. The results of this study are a series of efforts by H. Usman Mustakim to form community morals by providing an understanding of the concept of morality in the style of the prophet and should be able to integrate the personalities of the prophet Sulaiman A.S, the prophet Daud A.S, the prophet Yusuf A.S, and the prophet Muhammad Saw. The four prophets are a reflection of the personal ideal as a servant of Allah, encompassing intelligence, assertiveness and strength, beauty and gentleness, and nobility like the prophet Muhammad.
\end{abstract}

Keywords: Moral Formation, Sufism Approach, Usman Mustakim Thought 


\section{Introduction}

Today the world of education is faced with quite complex problems. Moreover, at the end of 2019, the outbreak of the coronavirus (covid 19) ${ }^{1}$ had a very significant impact on the world education climate. The Indonesian education world is overwhelmed in arranging strategies for implementing learning amid an epidemic, especially the government regulation on Large-Scale Social Restrictions (PSBB) increasingly narrows the space for the world of education to carry out learning activities ${ }^{2}$. Not to mention online learning which brings new problems by requiring every teacher and student to have software such as android, laptop, or tablet as a learning medium. What is most troublesome is that the significant impact of all of this is the change in the morals of students resulting from the absence of a teacher as a role model that can be seen directly. Because education is not only about teaching, but also the process of instilling values, ethics, or morals. ${ }^{3}$

\footnotetext{
1 Merry Dame Cristy Pane, Corona Virus, https://www.alodokter.com/virus-corona, (14/06/2020)

${ }^{2}$ Liputan 6, Indicator Survey: PSBB Should Not Be Loosened Up During a Pandemic, https: // www. coverage6. com / news / read / 4335681 / survey-indicators-psbb-not-worthy-loosening-duringpandemic-covid-19, (22/08/2020)

${ }^{3}$ Said Agil Husin Al Munawar, Actualization of Qur'anic Values in the Islamic Education System (Ciputat: Ciputat Press, 2005), p.
} 
Therefore, religion and the spiritual path are choices that can always provide good to every adherent. As stated by Komarudin Hidayat, there are several reasons why religion and Sufism need to be promoted; (1) Sufism or Sufi life has an important role in directing humans from confusion due to the erosion of religious spiritual values, (2) creating esoteric sources (kebatinan) of Islam, whether from among Muslims or non-Muslims, (3) asserting that the importance of the esoteric (kebatinan) aspect of Islam as the core or heart of Islamic teachings ${ }^{4}$. Although some people consider moral education with this kind of Sufism approach, it is considered promising, but by some circles, the spiritual path is often considered wrong.

But without us knowing it, Islam will never be separated from the basic practices or practices that make up the life of Sufism, praying and reciting the Koran are a must. For this reason, a community leader, Ntori Bima, who can be called H. Usman Mustakim, has his way of shaping community morals. Combining the four prophetic characters, then crystallized into one solid solid character, both in terms of knowledge, self-image, and noble morals. These practices were poured out on the children and their students. Even though now, not all of them still remember and practice their teachings. Therefore, this research is intended to raise again

${ }^{4}$ Junaidin, Challenges of the Age Against the Existence of Raso (Purification) Values in Sufism Moral Education in the Bima Ntori Society, Fitrah: Journal of Educational Studies, Volume 10 No. 


\section{Abdullab Thalib}

the efforts of $\mathrm{H}$. Usman Mustakim ${ }^{5}$ in shaping the morals of the Ntori Bima community. It should be reappointed to add to the repertoire of Islamic knowledge, which may not be a sticky thing but needs to be a reminder and motivation for us in cultivating perfect human beings.

\section{Literature Review}

Moral Formation

In simple terms, morals are synonymous with Islamic teachings because they relate to human nature. Fitrah means the potential to make Islam in humans which can be seen from the original character or character, as well as the potentials given by Allah SWT. Sufis (actors of Sufism) state that this potential is in the form of traits in humans, such as the 99 attributes of Allah's Asmaul Husna which were

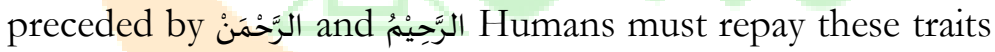
to Allah SWT by prioritizing the concepts of الرَّحِيْمُ and الرحمَنْ in the form of attitude. ta'bud to $\mathrm{Him}^{6}$ That is why the relationship between morals in Islam and Sufism is a family that both originates from the Koran and Hadith and is oriented towards the formation of morals ${ }^{7}$. Moral education certainly prioritizes praiseworthy practices, while in Sufism, morals are the ultimate goal.

${ }^{5}$ Ulama and Community Figures Ntori Bima.

6 Nasharuddin, Akhlak: Characteristics of a Complete Human (Depok: Rajawali Pers, 2015), p. 53-55.

${ }^{7}$ Abudin Nata, Sufism Morals and Noble Characters, p. 16. 
To understand the morals that are meant in this article, it is necessary to know that morals themselves are divided into two forms, namely mah easy morals or praiseworthy morals and mazmumah morals or despicable morals. First, Morals are easy. Mahampang morals are the opposite of mazmumah morals, a person will not be said to be a Muslim if he does not have such mah easy morals. This is because Islam is a religion that is filled with goodness and character $^{8}$, or in psychological studies, it is better known as personality. Al-Qur'an describes the full person in one of the surah Al-Imran / 3: 79

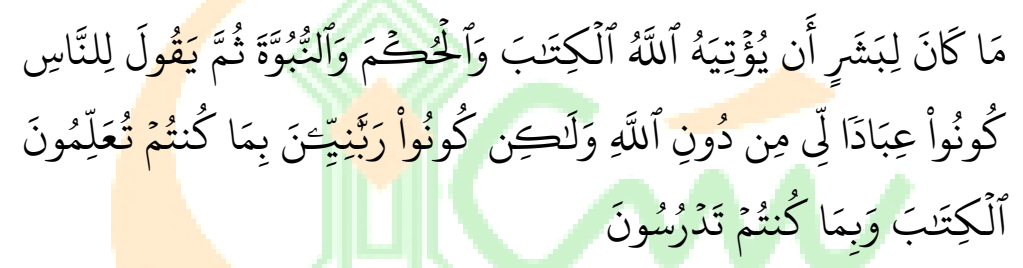

Translation:

It is not natural for a human being that Allah gave him the al-Kitab, wisdom, and prophethood, then he said to humans: "You should be my worshipers, not worshipers of Allah." However (he said): "You must be rabbaniy people. Because you always teach the Bible and because you keep on studying it.'

The word Rabbaniy in the verse describes personal perfection as a manifestation of a combination of faith, knowledge, and piety. These rabbaniy people are perfect p. 378

${ }^{8}$ Nasharuddin, Akhlak: Characteristics of Complete Humanity,

${ }^{9}$ Ministry of Religion of the Republic of Indonesia, Al-Qur'an and Translation (East Java: Halim, 2013), p. 60. 


\section{Abdullab Thalib}

beings, like the prophets, messengers, auliya, al-mu'min, almuttaqin $^{10}$, and pious people. The regeneration of this mah easy morals is what Islamic leaders want to continue to inherit and preserve until now, creating complete personalities with the perfection of Islamic teachings as a reflection of the attributes of the one and only God.

Second, Mazmumah morality, in moral terms mazmumah is despicable, whereas in terminology it is an act that is consciously committed and this is prohibited by someone from the teachings of Islam. Among these morals is the act of shirk or associating partners with Allah SW'T, as has been done by the Jews, Christians, and the majus.

\section{Sufism}

Sufism is a branch of science that was born from the results of studies on the separation of Islamic values so that Sufism is a part of Islam itself. As we all know, the teachings of Sufism are the fruits that are born from values based on the al-Qur'an and al-Hadith, because they are part of Islamic law. The teachings of Islam itself consist of two categories, namely; first, which is related to the external dimension (exetical) or related to the aspect of syari'at. Second, which relates to the inner dimension (esoteric). This aspect is related to Sufism because it relates to the manifestation of human

\section{p. 380}

${ }^{10}$ Nasharuddin, Akhlak: Characteristics of Complete Humanity, 
beings or one of the manifestations of the trilogy (the three frameworks of Islamic teachings) after faith and Islam.

According to Judge Abd. Hamed quoted St. Nurhayati Ali, said that a person whose mind is truly attached to Iman (belief in God), to Islam (fully surrendering to God), and carrying out Ihsan (doing good), then he is a believer ${ }^{11}$. Researchers interpret it that a true believer is one who practices these three aspects. Whether you believe in God, submit yourself to Allah SWT. wholeheartedly, and do good to all creatures. Sufism is a very important thing in human relations with Allah SWT. Sufism is a teaching that leads to purity of heart, recognition of oneself to recognize who God is. Ihsan itself is a virtue, but not a virtue but the pinnacle of virtue itself.

While faith is a justification by the heart, what is spoken by mouth and witnessed by the eye. Justification itself is not a justification that can be interpreted broadly but is related to anything brought by the Prophet Muhammad, which is described in the sixth pillar of faith, which is then believed and will give birth to concrete steps for things and concrete goals as well. Faith is related to principles, or values that will become benchmarks and reference. So that faith will be able to give birth to the strength of the heart and not

11 St. Nurhayati Ali, Sufism in the Modern Century (Solution to Human Problems According to Seyyed Hossein Nasr), p. 223 


\section{Abdullab Thalib}

weakness and complacency with dreams. Whereas Islam is surrender, and Muslims are people who surrender ${ }^{12}$.

Tasawuf akhlaki is tasawuf which is oriented towards improving and fostering moral character and has several parts $^{13}$, namely; (1) Takh alli, namely the efforts to empty oneself from despicable acts, which can be said to be emotional intelligence ${ }^{14}$. The first step, of course, we have to first find out what can empty itself, then delete it and avoid it. These despicable qualities include hasud, hirsh (excessive desire), istikbar, mace $>$ b, riya, sum'ah, uju $>$ b, s\} yi $>$ rk, and so on. Furthermore, the method of eliminating it is by living aqidah and worship which is then accompanied by riyadah and muhasabah (self-correction) ${ }^{15}$. (2) Tahalli, is an effort to fill and re-decorate the heart with commendable morals ${ }^{16}$, both external and internal. This means that every step of the way must always be based on religious knowledge. As for what is meant by the outward aspect, namely prayer, fasting, pilgrimage, and so on. Meanwhile, the inner aspect is faith,

12 M. Quraisy Shihab, Sowing Divine Messages (Cet. I; Jakarta: Lentera Hati, 2006), p. 17

${ }^{13}$ Junaidin, "Sufism Moral Values in Child Education in the Bima Ntori Community", Thesis, Makassar: PPS UIN Alauddin Makassar, 2018. 2017), p. 144.

14 Duski Samad, Sufistic Counseling (Depok: Rajawali Pers,

15 St. Nurhayati Ali, Sufism in the Modern Century (Solution to Human Problems According to Seyyed Hossein Nasr), p. 229.

${ }^{16}$ Duski Samad, Sufistic Counseling, p. 170. 
obedience, love for Allah SWT., and others. (3) Tajalli, means the disclosure of nur goib for the heart ${ }^{17}$.

The phase of takh\} alli is a phase of mental purification, soul, mind, heart so that it radiates outward and morals (morals) are noble and praiseworthy. Technically there are five methods of takh alli, namely; 1) To purify the unclean, by doing istinjak properly, thoroughly, and correctly using water or soil. 2) To cleanse the dirty, by bathing or pouring water all over the body in a good, thorough and correct way. 3) To purify the clean, utilizing ablution with water and dust in a good, thorough, and correct way. 4) Purifying the holy (fitrah) by establishing repentant prayers to ask forgiveness from Allah SWT. 5) Purifying the Most Holy, by doing dhikr and monetizing Allah with the words that there is no worship except Allah Ta'ala. ${ }^{18}$

According to HM. Amen. Gratitude tahalli is to decorate yourself by getting used to nature and attitude and good deeds. Meanwhile, Mustafa Zahri defines tahalli, namely decorating oneself with praiseworthy qualities ${ }^{19}$. Taking the stages of tahalli, the steps are to develop a person, so that they have al-kari mah morals, and always be consistent with the

${ }^{17}$ St. Nurhayati Ali, Sufism in the Modern Century (Solution to Human Problems According to Seyyed Hossein Nasr), p. 229.

18 M. Hamdani Bakran adz-Dzaky, Islamic Counseling and Psychotherapy Application of the Sufistic Method (Yogyakarta: Fajar Pustaka Baru, 2002, pp. 259-260.

19 Mustafa Zahri, Key to Understanding Sufism (Surabaya, PT. Bina Ilmu, 1998) h. 82-89 


\section{Abdullab Thalib}

steps initiated previously (in takh (alli). Doing strong psychological exercises to get used to good behavior, which in turn will produce a perfect human (insan kamil).

The emptying step in takh \{alli directly and illuminated with praiseworthy qualities (mah) mū dah), and divine attributes, including al-taū hid (absolute unity of God), al-tau bah (returning to the path good), al-z' uhdu '(the attitude of the heart to distance itself from the material world), al-hub' Allah (love of Allah), al-wara '(keeping oneself from haram and syubhat), al-sha ${ }^{-}$bru (steadfast and enduring) in facing all situations and conditions, al-fă $\mathrm{kr}$ (feeling a need for God) al-s' yu crew (an attitude of gratitude by using the blessings and mercy of Allah SWT functionally and proportionally), al -ridha > (willing to what he received), altawakal (surrendering to Allah swt. after trying his best), alqan'ah) (accepting the gift of Allah swt sincerely) and so on. After someone tries to go through these two stages, namely the takhalli and tahalli stages, then the third stage is tajalli.

According to M. Hamdani Bakran adz-Dzaky tajalli is the birth or emergence of a new existence from human beings namely new deeds, speech, attitudes and movements, new dignity and status, new attributes and characteristics, and new self essence ${ }^{20}$. That is what is called the victory of Allah swt. The birth of a person from new birth and in a new life and life is simply because of the help of Allah swt, the intercession

${ }^{20}$ Junaidin, "Sufism Moral Values in Child Education in the Bima Ntori Community", Thesis, Makassar: PPS UIN Alauddin Makassar, 2018. 
of the Prophet saw and the prayers of the angels by his side through effort, struggle, sacrifice, and very high discipline from oneself in performing acts of worship in the form of carrying out all of His commands, avoiding His prohibitions, and persevering in His trials. If referring to the values in Sufism, then it will be found the burden of ethics ${ }^{21}$, or in the language of Islam called morality ${ }^{22}$, in the view of Syamsul Nizar has the power to form social bonds ${ }^{23}$. So it can be considered as a path to moral therapy ${ }^{24}$.

Psychologically, Sufism results from various spiritual experiences and is a form of direct knowledge of divine realities that tend to be innovators in religion. Then the presence of God in a mystical form can give rise to a very strong conviction. Finally, the relationship with Allah SWT is established based on love. The morality which is the core of Sufism teaches people to protect themselves from neglecting their spiritual needs ${ }^{25}$. So that the main purpose of Sufism is

${ }^{21}$ Said Agil Husin Al-Munawar, Actualization of Qur'anic Values in the Islamic Education System (Ciputat: Ciputat Press, 2005), p. 3.

${ }^{22}$ Khaeruddin, Value Thinking and Ethics of Islamic Education (Makassar: Makassar Education Foundation, 2003), p. 152.

${ }^{23}$ Samsul Nizar, ed., History of Islamic Education: Tracing the History of Education from the Era of the Prophet to Indonesia (Jakarta: Kencana, 2007), p. 1.

24 Simuh, Sufism and Its Development in Islam, p. 57.

25 Arung Kiting, Papers of Sufism Various Opinions About the Emergence and Development of Sufism, http:/ / arungkiting.blogspot.co.id/search?q=esensi+tasawuf, $(19 / 08 / 2020)$ 
as a forum for moral therapy and a way to get closer to Allah SWT.

According to Imam al-Ghazali, when he started being a student of a Sufi, he had to go around the three main principles, namely khauf (fear), raja '(hope), and hub (love) ${ }^{26}$. As for the object of Sufism, studies is the human heart or soul. The discussion is not physical, because it is more about human physiology or biology, but the discussion of Sufism emphasizes more on the problem of the immaterial human soul. Cleansing or purifying the heart several things must be done to reach a high degree (maqam) with Allah SWT.

\section{Repentance}

The word repentance comes from the Arabic language, namely تَابَ- يَتُوْبُ تَوْبًا تَوْبَهُ which means to return from sinful deeds ${ }^{27}$. Repentance in the eyes of the Sufis means to purify oneself from the sins that have been committed. Repentance is a unity based on knowledge and deeds. Repentance based on science will give birth to things, then things will give birth to deeds. Knowledge will be able to give birth to awareness and guidance towards where and what to do in the process of purifying the soul ${ }^{28}$. According to Sheikh

${ }^{26}$ Al-Ghazali, Majmū 'ah Rasā' il al-Imā m al-Ghaz à li. Trans. Umar Faruq, The Way of Life of the Sufis (Cet. I; Surabaya, Pustaka Media Press, 2004), p. 10

${ }^{27}$ Mahmud Yunus, Kamus Arab-Indonesia, h. 39.

28 Al-Ghazali, Mukhtaśhār Ihyyā Ulumuddin, Terj. Junaidi Ismaiel, Intisari Ibya Ulumuddin, h. 484 
Abdul Qadir al-Jailani, likening the spiritual or soul state as children (thifli>) that must be taken care of. The heart is like a mother who takes care of her, breastfeeds her, and caresses her. Like this in the real world is taught physical science, while the heart teaches spiritual and divine knowledge ${ }^{29}$.

According to al-Ghazali, the Prophet saw said "nadmu> tau $>$ ba> tun" which means repentance is repentance $^{30}$. In this history, it can be said that repentance is an effort to purify oneself from sin in earnest not to repeat it. The encouragement to repent is also found in the words of Allah swt, namely QS al-Baqarah / 2: 222, as follows:

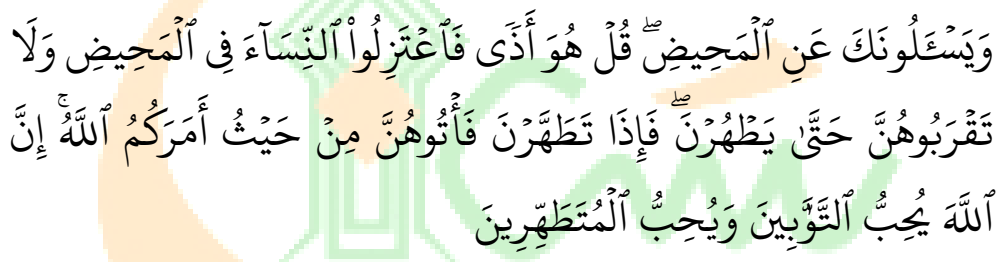

Translation

They ask you about menstruation. Say: "Menstruation is dirt". therefore you should stay away (meaning having sex with a woman during menstruation). from women during menstruation; and do not approach them until they are clean. When they are holy, then mix them in the place that Allah has commanded you.

29 Sikh Abdul Qadir Al-Jilani, Sir Al-Asrar Abdul Majeed Haj. Khatib (St. E., Jakarta: Guest Press, 2017), H. P.

30 Al-Ghazali, Mukhtaśhār Ihyā Ulumuddin, Terj. Junaidi Ismaiel, Intisari Ibya Ulumuddin, h. 484. 
Lo! Allah loveth those who repent and loveth those who purify themselves. ${ }^{31}$

Referring to these descriptions, although only partial but can illustrate how important repentance is to change the soul (purity), which is then to be able to approach the Most Holy. The defilement of the soul, heart, or sir is part of human behavior itself. Because man is born in a state of holiness and deserves to return in a state of holiness as well.

\section{Wara'}

The word wara 'comes from the Arabic وَرَعًا which means keep away from all sins (keep far from all sin), The general understanding of the Sufis, wara ${ }^{132}$ is to avoid far-fetched everything in which there is doubt between halal and haram (syubhat). Being a Sufi does not mean leaving the world at all.

Wara behavior is the life behavior of the companions of the prophet. Abubakar as-Shidiq advised, "we left seventy doors towards the halal because we were afraid of falling on one door towards the haram". While the Prophet Muhammad saw. said, which means; "Worship is ten tribes, nine of them in search of halal" so nine-tenths of worship are looking for halal. Therefore, the Prophet said "you should conduct good

31 Agus Hidayatullah, et al, Al-Jamil: al-Qur'an Tajwid Color: Word Translation: English Translation (Bekasi: Citra Bagus Segara, 2012), p. 35.

32 Firdaus Al-Hisyam and Rudi Hariyono, Complete ArabicIndonesian-English Dictionary (: Reality Publisher,), p. 626. 
deeds so that you become worshipers" ${ }^{13}$. Based on this description, researchers mean that wara 'behavior is an important thing in practicing Islam to avoid the fire of hell.

In terms of language, the word zuhud is usually defined as unhappy or unwilling to do something worldly. In general, the meaning of asceticism is that the heart does not depend on property, not that it does not have property. Zuhud is a better level after piety. The ascetic is more interested in the happiness of life in the hereafter than in the pursuit of mortal worldly life. Maqam zuhud is the most dominant maqam in the life of Sufis because in general, their lifestyle tends to leave the world. As for the virtue of asceticism is shown in QS al-Kahf / 18: 7, Allah swt says:

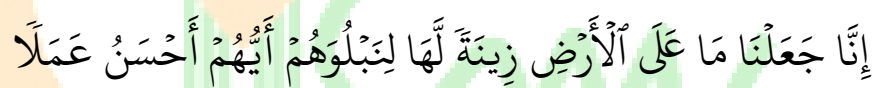

Translation:

Indeed, we have made what is on the earth an adornment for him, that we may test them, which of them is the best in deeds ${ }^{34}$

Referring to this verse, the researcher interprets that the world is only a piece of jewelry to eliminate boredom in humans for their taste and desire for various worldly pleasures. This parable is like a child who cries and asks for a toy, when the toy is given they are happy and play with it, but

33 Simuh, Sufism and Its Development in Islam, p. 54.

34 Agus Hidayatullah, et al, Al-Jamil: al-Qur'ā n Tajweed Color: Word Translation: English Translation, p. 293. 


\section{Abdullab Thalib}

over time he will feel bored and bored. In the end, they will look for something else that he likes, even until they grow up, get old and die. This is none other than a test for humans to be able to accept judgment from Allah SW'T.

So to save mankind from the world's deceit, Allah also provided a way of salvation (Islam) as a provision for living in the world. One such good advice is, as the narration of the Prophet Muhammad in the following book "the essence of ihya ulumuddin", the Prophet Muhammad SAW said, which means "If you see someone gifted with silence and zuhud in the world, be close to him because he can reveal wisdom." for people who do zuhud according to the Prophet Muhammad is to be loved by Allah. The history that confirms it, namely; "35If you want to be loved by Allah, zuhudlah from the world, surely Allah will love you" ${ }^{\prime 36}$.

Based on the sound of these descriptions, the researchers can conclude that zuhud is an attitude of staying away from worldly life and focusing on the afterlife. The term Sufism at this stage sometimes enters the stage of tahalli (emptying) were pursuing the virtues of the hereafter is prioritized, and one of its virtues is being loved by Allah SWT. However, this definition of zuhud should no longer be applied now, because at different times the experts

35 Al-Ghazali, Mukhtas hā r Iḥ yes̄ Ulumuddi n, trans. Junaidi Ismaiel, Intisari Ihya Ulumuddin, p. 535.

36 Al-Ghazali, Mukhtas hā r Ih yes̄ Ulumuddi n, trans. Junaidi Ismaiel, Intisari Ihya Ulumuddin, p. 535. 
formulated the modern Sufism concept which zuhud without having to ignore the life of the world.

\section{Fakir}

Poor words in terms of language are people who want, need or poor people. While in the view of the Sufis al-Fa> qr is not asking more than what is his right, not expecting much and asking for sustenance, except only to carry out the obligations to worship and draw closer to Allah swt. As Allah swt says to the poor, can be seen in QS Fà ț ir / 35: 15, namely:

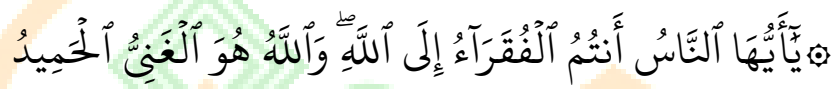

Translation

O people, it is you who will to Allah; and Allah is the Beneficent, the Praiseworthy ${ }^{37}$

Poor people are people who have nothing and need compassion from the all-powerful, namely Allā $\mathrm{h}$ Ajjā Wajallā h. Based on this, needy people will be grouped into several groups, namely: (1) people who hate property and stay away from it or are commonly referred to as zuhud experts, (2) people who do not shy away from the property but don't like it either. When there is wealth, he does not hate it, or what is known as someone willing (receiving). (3) people who like wealth. but when the property that he is working on is lost, he

${ }^{37}$ Agus Hidayatullah, et al, Al-Jamil: al-Qur'ā n Tajweed Color: Word Translation: English Translation, p. 436. 


\section{Abdullab Thalib}

does not worry too much about it (qanā 'ah)) or accept what is there, (4), a person who likes wealth, but he cannot find it because he is unable. (5) people who do not regret losing their property, even though it is their most important (primary) need, such a person is usually called zuhud ${ }^{38}$

Referring to this group, the best person is the one who does not change his mental condition even though his property is lost. This kind of thing was also expressed by the Prophet when answering the question of Umar bin Khatab's friend, he stated "faki run yu'tỉ y juh dahū" which means "the best human being is a poor person who gives based on his ability."

\section{Be patient}

The word patience can be meant to avoid things that are contrary to God's command, calm when getting a disaster or trial, and show the attitude of an officer even though he is actually in poverty in the economic field. According to the Sufis, patience consists of patience in carrying out the commandments of God, patience in avoiding all His prohibitions, and patience in accepting all the trials that are imposed. Patience is the key to success, more or less the advice of the wise. Al-Qur'an, there are at least 44 surahs that mention the words of patience. How Allah also narrated to the ummah of the Prophet Muhammad saw against the

38 Al-Ghazali, Mukhtas hā r Ih yes̄ Ulumuddi n, trans. Junaidi Ismaiel, Intisari Ihya Ulumuddin, p. 525. 
previous ummah caused by those who are unable to manage patients. The existence of these verses is not without a clear background, in QS al-Sajdah / 32: 24. Allah swt only gives superiority to those who are patient.

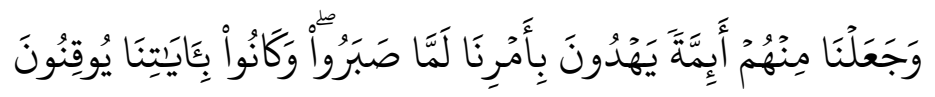

Translation:

And we made among them leaders who gave instructions with our commands when they were patient (in truth) and they believed in our verses. ${ }^{39}$

The verse explains that patience must be accompanied by truth. Apart from that, Rasulullah SAW. when a friend asked about faith, he said "as \s\obrū was \s\amā hatu" which means patience and tolerance. Not only that, but he also narrated "as $\backslash s \backslash$ obrū kand $\backslash z \bar{u} n$ min kunū z i i 1 jannā ti" which means patience is one of heaven's savings.

Al-Ghazali revealed that the essence of patience is a building consisting of knowledge, knowledge, and charity. If analogous to a tree, knowledge is the tree, the ahwal is the branch, and charity is the fruit ${ }^{40}$. The application of religion and sharia in general which is based on an attitude of patience and gratitude will be able to give birth to a very sweet charity.

39 Agus Hidayatullah, et al, Al-Jamil: al-Qur'ā n Tajweed Color: Word Translation: English Translation, p. 417.

40 Al-Ghazali, Mukhtas hā r Iḥ yes̄ Ulumuddi n, trans. Junaidi Ismaiel, Intisari Ihya Ulumuddin, p. 484. 


\section{Abdullab Thalib}

6. Tawakal

In the language, al-tawakkal means surrender or resuscitate. In terms of tawakal is the submission of a servant to Allah Almighty. after trying my best. The surrender that is meant is not merely surrendered. This means that after various efforts to purify oneself, fill oneself with praiseworthy practices and leave the despicable ones.

7. Ridha

The word happy in terms of language can be interpreted as willing, like, happy. Rida means not opposing qadha 'and qadar Allah, accepting qadha' and qadar sincerely, taking out hate from the heart so that what remains in it is only feeling happy and happy, feeling happy to get calamities as well as feeling happy to receive favors, and not feeling bitter and sick after receiving qadha 'and His qadar.

\section{Results And Discussion}

\section{Overview of Ntori Bima}

The Bima Regency Government in 2012 enacted the Bima Regency Regional Regulation Number 2 of 2012 concerning Village Expansion. The number of newly created villages is 23 new villages. So that the number of villages in Bima Regency in 2018 was 191 villages spread over eighteen sub-districts. Before the enactment of Perda No.2 of 2012, the number of villages in Bima was 168 villages, or 18 subdistricts. As for the names of the villages in Wawo District; 
(1) Maria Utara Village, (2) Maria Village, (3) Pesa Village, (4) Kambilo Village, (5) Kombo Village, (6) Ntori Village, (7) Raba Village, (8) Tarlawi Village, (9) Riamau Village.

Ntori Village is located at an altitude of 250 meters above sea level and can be reached via the Bima-Sape highway only 16 kilometers from Raba - Bima City via a climbing and winding road. Wawo sub-district is located at an altitude of $250 \mathrm{M} \mathrm{DPL}$ and is at $2310 \mathrm{LU}$ with $90 \%$ of the area in the form of a plateau.

Biography of H. Usman Mustakim

H. Usman bin Mustakim bin Hudi At-Hija was born in Ntori-Bima on July 12, 1942, to a mother named Samida and a father named Mustakim. He is a scholar as well as a community leader in Ntori Bima Village who is influential in the community of Ntori Bima Village, Wawo District, in particular, has 3 wives and 7 children. From his first marriage to Jaenab's mother, he was blessed with 2 children named Sarla and Ramlin. When his first wife died, he married Kalisom's mother and was blessed with 4 children, namely Misbah, Masdar, Yusuf, and Mushaf. After his second wife also died, he re-married Saadiah's mother and was fertilized by a daughter named Suhaina. ${ }^{41}$

His history of formal education began with taking Islamic Religious Education at the Maria National People's School (SRN) in 1953, Madrasyah Islam (MI) Maria in 1956,

\footnotetext{
${ }^{41}$ Saadiah, Interview, 22/08/2020.
} 
Islamic Middle School (SMI) Raba in 1959, First Religion Teacher Education (PGAP) Bima in 1961, The 6 Year Bima State Religion Teacher Education (PGAN) in 1970, and ended by taking a D II majoring in Islamic Religious Education at the Mataram branch of IAIN Sunan Ampel Surabaya in 1996. While non-formal education started from Public Schools, TU Islamic Religious Education, Project for Quality Improvement organized by the Ministry of Religion of West Nusa Tenggara in 1976 for 10 days. Eight years later, he returned to the Bima District Public Works Type A course which was held by PEMDA Bima in 1984 for 15 days. ${ }^{42}$

The work history began to be appointed as a Civil Servant (PNS) Religion Teacher at MI Bajo, Kempo District, Dompu Regency on August 1, 1962, with class I / c. Then on 1 September 1970, he was transferred to SMPN 1 Wawo as a Religion Teacher with class II / b. His career took off again by being appointed as Principal of MIS Maria School, Wawo District, Bima Regency on November 1, 1991, with a rank of III / $\mathrm{a}^{43}$. However, according to his wife Saadiah, H. Usman Mustakim before moving to SMPN 1 Wawo, he had taught at MI Wawonduru, Dompu Regency, SDN Teta Bima Regency, MI Sape in Bima Regency, only after that he moved to Wawo District $^{44}$.

42 Ministry of Religion of the Republic of Indonesia, Civil Servant Card, Documents, 2001.

43 Ministry of Religion of the Republic of Indonesia ...

${ }^{44}$ Saadiah, Interview, 22/08/2020. 
His dedication as a community figure and cleric did not end there, he was once the Chairperson of KPPS III Ntori Village, Sape District on October 25, 1977 $7^{45}$. Then again he was trusted to be the Chairperson of KPPS Ntori in the 1982 general election with charter number W.II.06.044 / PT / $1982^{46}$. According to "Ama Sala", who is now over 80 years old, da'wah activities continue to be carried out by becoming an idol preacher in Wawo sub-district, whether preacher Friday or $\mathrm{Id}^{47}$. This statement was later confirmed by a student of H. Usman Mustakim, who also happened to have taught at MIS Maria when he was the principal of the school ${ }^{48}$.

His influence as a cleric also has its charm, so that prayers and blessings from him are often sought and asked by the people of Wawo and Bima district before taking school exams, employee tests, or other such things. He did this even until the closing seconds of his age, losing the figure of ulama like him left grief for everyone, especially for his students who were in formal schools and society. His thought that most influenced his students was the concept of moral education in the style of the prophet, which was often taught through practices in sunnah worship. Starting from midnight prayer, fasting, almsgiving, and zakat, to daily prayers.

45 Ministry of Home Affairs / Regional General Election Institutions Level I, Award Charter, 25/10/1977.

46 Ministry of Home Affairs / General Election Institution, Award Charter, Jakarta: 04/11/1982 22/08/2020.

47 M. Ali Ama sala, H. Usman's Life Story, Interview,

${ }^{48}$ Kartini, The Life Story of H. Usman, Interview, 21/08/2020. 


\section{Abdullab Thalib}

His influence as a cleric also has its charm, so that prayers and blessings from him are often sought and asked by the people of Wawo and Bima district before taking school exams, employee tests, or other such things. He did this even until the closing seconds of his age, losing the figure of ulama like him left grief for everyone, especially for his students who were in formal schools and society. His thought that most influenced his students was the concept of moral education in the style of the prophet, which was often taught through practices in sunnah worship. Starting from midnight prayer, fasting, almsgiving, and zakat, to daily prayers.

Efforts to Build Morals through the Sufism Approach

The formation of morals using the Sufism approach by $H$. Usman Mustakim has its characteristics. The uniqueness in question is the addition of the concept of moral formation that combines four prophets at once who are then used as role models in social life. The efforts in question are; 1) straightening aqidah and understanding, 2) habituation of compulsory practice, 3) building morals.

a. Straightening Aqidah and Understanding

Before the entry of Islam, the Wawo people already had two basic beliefs, namely; (1) Belief in spirits (parafu), and (2) belief brought by Hindu influence during the heyday of the Majapahit Kingdom. This Hindu influence is profound and can only be removed for a long time. As historical 
evidence that in Maria Village, Wawo District, there are two places of worship for them; Waro Lanco Ele (east lanco) and Waro Lanco Di (west lanco). ${ }^{49}$

After the collapse of Majapahit, Islam entered Bima Regency in general and Wawo District in particular, namely in 1617 AD. According to the story, the Wawo (Maria) people came from the island of Sumatra (Minangkabau). However, before arriving at the land of Bima (Dana Mbojo), they stopped at Kampung Tolaka, Sulawesi. As a result of being pressed by the indigenous people of Tolaka, they wandered to the eastern part of Sumbawa Island by boat ${ }^{50}$. The connection with this research is to emphasize the cultural differences and beliefs of Ntori Bima Village with Maria Village which is still thick with animism and dynamism or some people call it local religion (parafu). Meanwhile, Ntori Bima Village has abandoned such a belief, this is also the background for moving the location of Ntori Bima Village from Maria to Ntori which is now. Although it cannot be denied, the mingling of the descendants of Maria Village has added a new task for the scholars to straighten their aqidah.

Ntori Village is divided into two groups, the first group is the original descendants which are divided into Ntori Hamlet, Sigi Hamlet and Bedi Hamlet and the second group $04 / 10 / 2020$

49 Observation, Traces of Parafu Faith in Maria Village, 50 Wawo District Overview, http:/ / mbojonet.blogspot.com/2012/06/gambaran-umum-kecamatanwawo.html, (13 October 2018). 


\section{Abdullab Thalib}

is descendants of Maria Village who live in Kampo Ntori Hamlet. For the Da'wah route, H. Usman Mustakim divides the two types of preaching. In the first group, there is more emphasis on the importance of Islamic law. This is because the indigenous people are a group that is engaged in the zuhud life of the Sufis (Sufism actors). However, over time, their offspring who practice this knowledge only emphasize the study of its nature without being accompanied by the fulfillment of compulsory first worship. Starting from the level of sharia, nature, and makrifat. So that H. Usman's preaching in the first group focused more on the habit of compulsory worship; 1) inviting prayer, 2) fasting, 3) and reading the holy book al-Qur'an ${ }^{51}$.

In the second group, da'wah is often done directly through the pulpits of the preacher as an effort to purify the beliefs of the community, one of which he often conveyed is about the sin of shirk. One form of belief of the people of Desa Maria descent who now reside as villagers of Desa Ntori Bima is "Ncara Nggee" ${ }^{52}$. As the words of Allah SWT are often conveyed by H. Usman; ${ }^{.53}$

${ }^{51}$ H. Jafar (Abu Jefo), Narrated by Dakwak H. Usman Mustakim, $04 / 10 / 2020$

52 Kepercayaan masyarakat yang menganggap sakit, bala dan bencana, serta kematian disebabkan oleh penempatan suatu pohon atau rumah yang tidak sesuai.

${ }^{53}$ H. Jafar (Abu casting), Riwayat Dakwak H. Usman Mustakim, images, 04/10/2020 


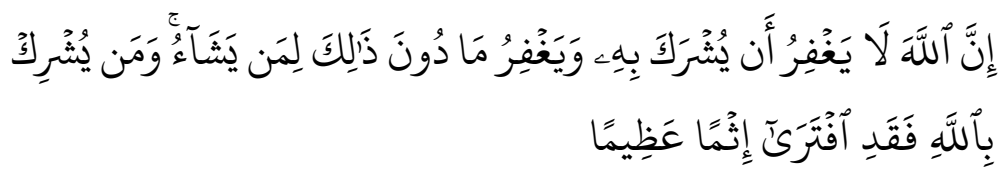

Translation:

Lo! Allah will not forgive the sin of polytheism, and He will forgive all sins other than (polytheism), for whom $\mathrm{He}$ will. Whoever associates partners with Allah, then he has committed a great sin. (QS. AnNisaa / 4: 48)

This is one of the tough tasks for preachers in Wawo District in general, Ntori Village in particular. Broadcasting the importance of purifying tauhid has faced challenges from the local community. As an example of shirking referred to; one of the family is sick but it is difficult to cure it, then the family will find out the type of disease in the smart person "sando". So that it can be known the cause of the disease. Usually, the cause that happens according to them is "ncara nggee oma" (wrong field position). The people of Mary and their descendants believe that if the position of the fields, gardens, houses is wrong, it will bring disaster. For example, a researcher interview with one of the residents of the Ntori Village, Descendants of Maria, below;

"Ade kanggihi kaina Nggaro ro oma, nami maria tiloa ta awa ma kacumpu kai, harus su'u ba ma na'e. Tiloa su'u ba matoi sae dohon. Misampa ta awa la suka, ta ese la mina. De tiloa ede" 54

${ }^{54}$ Ismail, Belief of the people of Mary, Interview, 04/10/2020. 


\section{Abdullab Thalib}

Translation

In farming, we maria are not allowed to be under the youngest, we have to carry the big leh. Should not be carried by their little brother's ole. For example, under the Like and above the Mina. Yes, you can't.

The point is that in the tradition of the maria, it is not permissible to place their fields under the position of their brother's. This will cause pamali, and bring harm to him and his descendants. H. Usman often said that nothing brings harm except with the permission of Allah SWT. Like the verse he usually quotes below;

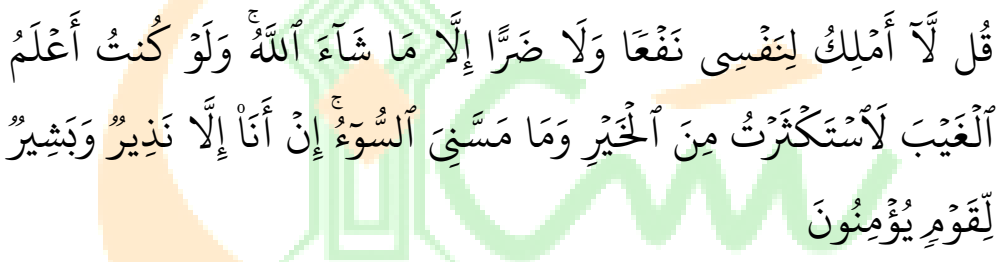

Translation:

Say: "I have no power to take advantage of myself, nor do I reject harm except that which Allah wills. and the bearer of good news for the believers ". (QS. AlA'Raaf / 7: 188)

This is closely related to the purity of our faith so that we must straighten our aqidah and Islam.

b. Amaliah-Amaliah Sunnah

The sunnah practices that are often recommended are midnight prayer, fasting, and almsgiving. First, the virtues of night prayers or midnight prayers often inspire, this is 
inseparable from the virtues of night prayers (tahajud). As Allah SWT says;

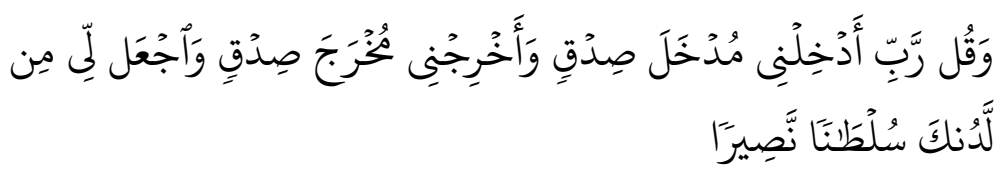

Translation:

"And on some nights of prayer tahajudlah you as an additional worship for you; May your Lord raise you to a Praiseworthy place"

According to H. Usman Mustakim, midnight prayer is a characteristic of someone who has a commendable position with Allah accompanied by love. Apart from these virtues, the midnight prayer will simplify all of our affairs (QS. Al-Israa / 17: 80$)^{55}$ and is the main prayer after fardhu prayer. As the following hadith says; "The most important prayer after fardhu prayer is night prayer" (Narrated by An Nasa'i).

At first glance, the practice is not much different from midnight prayer in general, but the difference is the number of rokaat and surah read, and the number of times it is read. The number of rokaat in the midnight prayer taught by him is 2 - 98 rokaat and closed with 1 rokaat witir. The number of rokaat in the midnight prayer must be an odd multiple of witir, ranging from 3 - 99 rokaat. This depends on the abilities of each individual, but the recommendation is often to take the

55 See the Ministry of Religion of the Republic of Indonesia, AlQur'an, and Translation 


\section{Abdullab Thalib}

number 33 rokaat $^{56}$ with the witir. Read surah al-Ikhlas every 33 times in each rokaat. According to H. Usman Mustakim, a multiple of 3 is a characteristic of the sunnah of the prophet Muhammad, such as taking ablution water, which is always a multiple of 3 every time you wash it

Second, Fasting Monday Thursday. Monday fasting is carried out the same as usual in Islamic teachings, with extraordinary virtue. As the hadith of the Prophet Saw;

From Abu Harrairah Radiallahu anhu, Rasulullah Sholallahu Alaihi Wassalam once said: "The gates of Heaven are opened on Monday and Thursday. Then all servants who do not associate Allah with anything will be forgiven for their sins, except for someone whose enmity occurs between him and his brother. Then it was said, 'Postpone the forgiveness of these two people until the two of them are reconciled, postpone the forgiveness of these two people until both of them are reconciled, postpone the forgiveness of these two people until both of them are reconciled.' $\left(\right.$ HR. Muslim) ${ }^{57}$

The difference is that the intention of the Monday fast is not required to use Arabic and is more dependent on the ability to memorize the intention. This practice must be done to cleanse oneself from $\operatorname{sins}^{58}$, because on Monday and Thursday, the gates of heaven will open.

${ }^{56}$ Kartini, Ajaran H. Usman Mustakim, Interview, 23/08/2020.

${ }^{57}$ See Sahih Muslim Book no. 2565

58 Kartini, Ajaran H. Usman Mustakim, Interview, 23/08/2020. 
Third, Issue Alms. The alms that are meant in the practices taught by him is to give alms to orphans, old widows, needy and poor to ask forgiveness from Allah SW'T and purify themselves from all kinds of sins. The alms are also given to animals, for example, such as chickens ${ }^{59}$. This is as the word of Allah SW'T;

Translation:

"There is no good in most of their whispers, except the whispers of people who tell (humans) to give alms, or do good deeds, or Make peace between people. And whoever does so for the sake of Allah, then We will give him a great reward. "

The virtue of people who practice sunnah practices is always focused on the nobility of character and character. The reward for giving alms is very tantalizing, as the verse says. This has become one of the basic ideas of $\mathrm{H}$. Usman Mustakim why he calls for charity according to his ability. Even with animals, as in the story of a prostitute who died and ended up going to heaven just for giving a thirsty dog to drink with his shoes.

\section{c. Moral Formation}

Basically, according to H. Usman Mustakim, speaking morals means talking about who our true idols are, cou ndaike (who we are), couku ndei batu ta (who we follow). Therefore,

59 Saadiah, Teachings of H. Usman Mustakim, Interview, 22/08/2020. 


\section{Abdullab Thalib}

according to him, a good Muslim needs to choose who his role model is. In Islamic teachings, there are 25 prophets and messengers that we must believe in, all of which are recognized in Islamic teachings. However, the position of the prophet Muhammad as a role model for Muslims is still deemed necessary to also idolize other figures of Allah's prophets. This is a very urgent matter in shaping the morals of an individual.

The formation of morals in $\mathrm{H}$. Usman's understanding wants to combine the characters of the 4 prophets and apostles so that they form a crystallization of character for each of the practitioners. The prophets in question are the prophet Sulaiman A.S, the prophet Daud the A.S, the Prophet Yusuf AS, and the prophet Muhammad $\mathrm{SAW}^{60}$. However, the purpose of the selection of these four prophets was often hidden by him from his disciples, except for certain students. As for the concept, he wants the intelligence of the prophet Solomon AS who can even talk to ants, reflected in the sentence "innahu min sulaiman wa innahu bismillahirrahmanirrahiim, wise and firmly the prophet David AS depicted in the sentence innahu min daud wa innahu bismillahirrahmanirrahiim, polite and handsome Prophet Yusuf AS which is described in the sentence innahu min yusuf wa innahu bismillahirrahmanirrahiim, and then perfected with the noble morals of the prophet as well as the

${ }^{60}$ Junaidin, Ajaran H. Usman Mustakim, Interview, 20/08/2020 
Prophet Muhammad through the sentence innahu min muhammad wa innahu bismillahirrahmanirrahiim "61.

\section{Conclusion}

The efforts to purify Islamic aqidah by H. Usman Mustakim are now starting to fade along with his death. However, the traces of his thoughts have always been the lips of the people of Ntori Bima Village. Moreover, the concept of moral formation expressed by $\mathrm{H}$. Usman Mustakim sounded familiar, because it was only taken from four prophets who in their history had their respective advantages, namely; 1) prophet Sulaiman A.S, 2) prophet Daud A.S, 3) prophet Yusuf AS, and 4) prophet Muhammad SAW. But the reason for making a concept from the four noble prophets makes this research interesting enough to be appointed as a scientific work. The order of the positions of the prophets also deserves a question. So that it is considered capable of being a talisman of life in the glasses of Sufism by the practitioner.

The combination of the four prophetic characters represents the vision and mission of Islamic education, starting from; 1) the virtue of knowledge which is illustrated by the breadth of knowledge of the figure of the prophet Solomon AS who can even talk to ants, 2) thinking rationally and believing in the omnipotence of Allah SWT through the

61 Mushaf, Teachings of H. Usman Mustakim, Interview, 20/08/2020. 


\section{Abdullab Thalib}

figure of the Prophet David AS, 3) gentle, forgiving and devoted to parents who are reflected through the figure of the prophet Yusuf AS, 4) as well as the honesty and moral dignity of the prophet Muhammad. The four prophets each had noble morals and morals, which even with the advantages they had did not make these perfect beings feel arrogant. This kind of intelligent, rational, gentle, and honest human character will be considered the heirs of the prophets, scholars, and pious people who can have a good impact on social life.

\section{REFERENCES}

Al-Ghazali. Majmu'ah Rasa'il al-Imam al-Ghazali. Trans. Umar Faruq. The Sufi Way of Life. Surabaya: Pustaka Media Press, 2004.

Al-Hisyam, Firdaus, and Rudi Hariyono. Complete ArabicIndonesian-English Dictionary 3. 1: Reality Publisher,

Ali, St. Nurhayati. "Sufism in the Modern Century: Solutions to Human Problems According to Seyyed Hossein Nasr". Dissertation. Makassar: PPS UIN Alauddin Makassar. 2013.

Al-Jailani, Sheikh Abdul Qadir. Sirr al-Asrar Fi Ma Yathaj Ilayh al-Abrar. Trans. Abdul Majid Hj. Preacher. Sir Al-Asrar. Yogyakarta: Diva Press. 2017. 
Al-Munawar, Said Agil Husin. The actualization of Qur'anic Values in the Islamic Education System. Ciputat: Ciputat Press. 2005.

Ministry of Religion of the Republic of Indonesia. Al-Quran and Translation. East Java: Halim. 2013

Duski Samad. Sufistic Counseling. Depok: Rajawali Press. 2017

Hamdani, Bakran adz-Dzaky M. Islamic Counseling and Psychotherapy Application of Sufistic Methods. Yogyakarta: Fajar Pustaka Baru. 2002.

Hidayatullah, Agus, et al. Al-Jamil: al-Qur'an Tajwid Color: Word Translation: English Translation. Bekasi: Citra Bagus Segara. 2012.

Junaidin. "Tasawuf Moral Values in Child Education in the Bima Ntori Society". Thesis. Makassar: PPS UIN Alauddin Makassar. 2018.

Junaidin. The Challenges of the Age Against the Existence of Raso (Washing) Value in Sufism Moral Education in the Bima Ntori Community. Fitrah: Journal of Educational Studies. Volume 10 No. 12019

Khaeruddin. Value Thinking and Ethics of Islamic Education. Makassar: Makassar Education Foundation. 2003.

Liputan 6. Survey Indicators: PSBB Is Not Worth Loosening Up During a Pandemic. https: // www. coverage6. 
com / news / read / 4335681 / survey-indicatorspsbb-not-worthy-loosening-during-covid-19 pandemic. 22/08/2020

Merry Dame Cristy Pane. Coronavirus. https://www.alodokter.com/virus-corona. $14 / 06 / 2020$

Nasharuddin. Morals: Characteristics of Complete Human. Depok: Rajawali Press. 2015

Nata, Abudin. Sufism Morals and Noble Character. Cet. To XIV; Jakarta: Rajawali Press. 2015.

Nizar, Samsul. History of Islamic Education: Tracing the History of Education from the Era of the Prophet to Indonesia. Jakarta: Golden. 2007.

Quraish Shihab, M. Sowing Divine Messages. Cet. I; Jakarta: Heart Lantern. 2006.

Said Agil Husin Al Munawar, Actualization of Qur'anic Values in the Islamic Education System. Ciputat: Ciputat Press. 2005.

Simuh. Sufism and Its Development in Islam. Jakarta: PT. Raja Grafindo Persada. 2002.

Yunus, Mahmud. Arabic-Indonesian Dictionary. Jakarta: PT. Mahmud Yunus Wadzuryah. 1972.

Zahri, Mustafa. Keys to Understanding Sufism. Jakarta: Qalam. 2014. 